Dr ĐOKO TRIPKOVIĆ, naučni savetnik

Institut za savremenu istoriju

UDK 339.92(497.1:47)"1971/1980"

Beograd, Trg Nikole Pašića 11

327:339(497.1:47)"1971/1980"

\title{
USPON EKONOMSKE SARADNJE IZMEĐU JUGOSLAVIJE I SSSR 1971-1980*
}

\begin{abstract}
APSTRAKT: U članku se razmatraju ekonomski odnosi između Jugoslavije i SSSR-a tokom sedamdesetih godina 20. veka. U tom periodu došlo je do dinamičnog uspona ekonomske saradnje između dve zemlje koji se prvenstveno izražavao kroz visoku stopu rasta robne razmene, a ostvareni su značajni rezultati i na polju industrijske kooperacije i graaevinarstva. Sve obimnija i kvalitetnija ekonomska saradnja bila je odraz pozitivnog stanja i stabilnosti medusobnih političkih odnosa, kao i evidentnog interesa dveju strana za proširenjem i jačanjem privrednih veza i saradnje.
\end{abstract}

Ključne reči: Jugoslavija, SSSR, Tito, Brežnjev, ekonomska saradnja

U poslednjoj deceniji života i upravljanja dvema komunističkim zemljama, Josip Broz Tito i Leonid Brežnjev su uspostavili i održavali stabilne političke odnose između Jugoslavije i SSSR-a. Dvojica lidera, mada pritisnuti godinama i sve lošijim zdravljem, bili su tokom 70-ih godina 20. veka vrlo aktivni u izgradnji dobre političke komunikacije, kako među njima lično tako i između dve zemlje. Sama činjenica da su se u periodu od 1971. do 1979. sastali osam puta (u proseku jednom godišnje) govori o visokom stepenu zainteresovanosti obe strane za održavanjem stabilnih političkih odnosa i za daljim razvojem bilateralne, prvenstveno ekonomske saradnje. Ovakav politički ambijent u odnosima Beograda i Moskve bio je kontinuirano na delu od posete Brežnjeva Jugoslaviji, septembra 1971, i nije u osnovi bio ozbiljnije poremećen sve do kraja ovog perioda - izvesni zastoji i zahlađenja predstavljali su samo prolazne epizode (sporadična ideološka sporenja, tretman ibeovaca, poseta kineskog lidera ... Fenga Jugoslaviji 1978).

* Rad je deo projekta Srpsko društvo u jugoslovenskoj državi u 20. veku: između demokratije i diktature, (177016), koji je finansira Ministarstvo prosvete, nauke i tehnološkog razvoja Republike Srbije. 
Tadašnje rukovodeće garniture ovih zemalja očito su bile čvrsto opredeljene da idu linijom unapređenja političke komunikacije, a samim tim i međudržavne saradnje, da više ne dopuste pad u odnosima poput onih koji su se dogodili posle sovjetskih vojnih intervencija u Mađarskoj (1956) i Čehoslovačkoj (1968).

Ekonomski odnosi između Jugoslavije i SSSR-a su u osnovi delili sudbinu političkih odnosa, s tim da oni ipak nisu u vremenima velikih zahlađenja u političkoj komunikaciji trpeli tako drastičan pad. Ta okolnost svedoči da su obe strane smatrale korisnim održavanje privrednih veza i saradnje, čak i u vremenima loših političkih odnosa. Ipak, opšti politički kontekst je imao presudan uticaj na razvoj ekonomskih odnosa, tako da su periodi uspona i stagnacije na tom planu bili odraz stanja u političkim odnosima. Tako su istorijsko političko pomirenje Beograda i Moskve 19551956. propratili brojni privredni aranžmani i sporazumi (neki od njih su karakterisani kao spektakularni). Onda je usledio period zastoja (19571961) koji je nastupio posle mađarske krize, tokom kojeg nije bilo novih ekonomskih aranžmana i podsticaja, ali je bilo mnogo problema u pogledu realizacije sklopljenih sporazuma (sovjetska strana je neke od njih jednostrano otkazivala ili odlagala primenu). Novo otopljenje odnosa početkom 60-ih, susreti na vrhu Tita i Nikite Hruščova 1962-1963. dali su snažan impuls privrednoj saradnji dve zemlje. Tokom narednih godina beležen je veliki uspon, koji se na prvom mestu odražavao kroz visok rast robne razmene, a u manjoj meri na planu industrijske kooperacije. SSSR je 1968. izbio na treće mesto u spoljnotrgovinskoj razmeni Jugoslavije (odmah iza Italije i SR Nemačke). ${ }^{1}$

Jako zahlađenje odnosa povodom vojne intervencije u Čehoslovačkoj 1968, koju je jugoslovensko rukovodstvo žestoko osudilo, nije, kako se moglo očekivati, proizvelo značajnije poremećaje na polju ekonomske saradnje. Sovjetski vrh je, i pored „ogorčenosti“ zbog jugoslovenskih reakcija, poručio još u ranoj fazi ovog zahlađenja ispunjenog teškim optužbama s obe strane i gotovo dramatičnim narastanjem tenzija da ne žele da se aktuelni politički sukob negativno odrazi na ekonomsku i vojnu saradnju između dve zemlje, te da imaju nameru da sa svoje strane nastave izvršenje važećih sporazuma i ostalih aranžmana iz ovih oblasti. ${ }^{2}$ U Beogradu je ovo obaveštenje dobro primljeno, jer je takav stav sovjetskog vođstva značio ne samo zadržavanje kontinuiteta u ekonomskim odnosima za čim je postojao

\footnotetext{
${ }^{1}$ O političkim odnosima i bilateralnoj saradnji Jugoslavije i SSSR-a videti: Đ. Tripković, Jugoslavija - SSSR 1956-1971, Beograd 2013, 111-205.

${ }^{2}$ Ovakav stav Kremlja saopštio je Nikolaj Podgorni, predsednik Vrhovnog sovjeta SSSRa Dobrivoju Vidiću, jugoslovenskom ambasadoru u Moskvi. - Arhiv Jugoslavije (AJ), 507, IX, 119/I-352, Beleška o razgovoru Dobrivoja Vidića i Nikolaja Podgornog, 11. septembar 1968.
} 
evidentan interes već je to bio i indikator koji je ukazivao na opredeljenost Kremlja da ne ide na dalje zaoštravanje političkih odnosa sa Jugoslavijom i ostavljanje prostora za njihovo popravljanje u budućnosti.

Upravo se to i dogodilo. Od sredine 1969, kada je u sovjetskom vrhu doneta odluka da se ide na postepeno poboljšavanje odnosa sa Jugoslavijom - čiji je izraz bila poseta Andreja Gromika Jugoslaviji početkom septembra - počelo je postupno otopljavanje klime u političkoj komunikaciji između Beograda i Moskve. Ipak, bile su potrebne dve godine da dođe do pune normalizacije odnosa i njihovog podizanja na najviši politički nivo, što je označeno posetom Leonida Brežnjeva Jugoslaviji krajem septembra 1971. ${ }^{3}$ Tokom te tri godine, ekonomski odnosi su se odvijali kako je bilo i najavljeno iz Moskve a prihvaćeno u Beogradu: korektno i bez većih problema i nesporazuma sprovođeni su postojeći sporazumi, ali je bio primetan izostanak inicijativa za sklapanje novih aranžmana koji bi išli u pravcu nekog ambicioznijeg proširenja i dinamiziranja ekonomske saradnje između dve zemlje.

Poseta Brežnjeva i razgovori koji su tom prilikom vođeni u Beogradu otvorili su perspektivu za postavljanje političkih odnosa na znatno kvalitetnije i stabilnije osnove, pri čemu je ključni element bilo jasno uvažavanje međunarodne pozicije Jugoslavije i modela njenog socijalističkog uređenja od strane SSSR-a, što je Brežnjev i u razgovorima sa Titom i u zajedničkim izjavama i dokumentima koji su tom prilikom potpisani nedvosmisleno potvrdio. Na ovom susretu na najvišem političkom nivou obe strane su dale snažan podsticaj unapređenju bilateralne, posebno ekonomske saradnje. U zajedničkoj izjavi od 25. septembra se u vezi s tim navodi: „Dve strane su uverene da postoje velike mogućnosti za proširivanje i produbljivanje ekonomske i naučno-tehničke saradnje između SFRJ i SSSR-a. Osnovni pravci daljeg razvoja jugoslovensko-sovjetskih odnosa su proširivanje robne razmene, uzajamno korisne kooperacije i specijalizacije proizvodnje, a takođe i projektantskih i istraživačkih radova, naročito u onim granama koje opredeljuju savremeni naučno-tehnički progres".

Snažan politički podsticaj rezultirao je u narednim mesecima nizom praktičnih koraka koji su vodili značajnom proširenju privredne saradnje dve zemlje. U decembru 1971. prilikom posete Jugoslaviji Nikolaja Bajbakova, potpredsednika sovjetske vlade, potpisan je protokol o ekonomskoj saradnji između Jugoslavije i SSSR-a za period do 1980. godine. Delegacije dve vlade na visokom nivou sastale su se i $u$ avgustu naredne godine $u$ Moskvi (jugoslovensku delegaciju je predvodio Jakov Sirotković, potpredtembar 1971.

${ }^{3}$ Više o poseti Leonida Brežnjeva Jugoslaviji u 1971: Đ. Tripković, n. d., 280-287.

${ }^{4}$ Kominike o poseti i zajednička izjava o odnosima između dve zemlje, Politika, 26. sep- 
sednik SIV) kada se razgovaralo o realizaciji postignutih dogovora i sporazuma u prethodnih godinu dana. U razgovoru predsednika jugoslovenske $\mathrm{i}$ sovjetske vlade, Džemala Bijedića i Alekseja Kosigina, u Moskvi 13. juna 1972, problematika ekonomske saradnje predstavljala je važan segment u razmatranju bilateralnih odnosa između dve zemlje. Prilikom posete Kosigina Jugoslaviji krajem septembra 1973. (sastao se i sa Titom), Bijedić i Kosigin su konstatovali da postoje povoljne mogućnosti za unapređenje jugoslovensko-sovjetske saradnje u različitim oblastima. Posebno je izvršena široka razmena mišljenja o ekonomskim odnosima i s tim u vezi su se saglasili o potrebi konsultacija spoljnotrgovinskih i planskih organa dve vlade kao i o zaključivanju dugoročnih aranžmana o poslovnoj saradnji, naročito na polju zajedničke izgradnje industrijskih i drugih objekata, proizvodne kooperacije i naučno-istraživačke delatnosti. I u razgovoru Tita sa Kosiginom najviše reči je bilo o ekonomskoj situaciji i mogućnostima proširenja ekonomske saradnje. $^{5}$

Na još dva politička samita tokom Titovih poseta Sovjetskom Savezu juna 1972. i novembra 1973. istican je veliki značaj i obostrani interes za proširenje ekonomskih i trgovinskih odnosa. Na oba sastanka vođena je široka diskusija o ovoj tematici, a visoki vladini funkcioneri s obe strane su podnosili izveštaje o stanju u ekonomskim odnosima i planovima za unapređenje saradnje. Politička rukovodstva su usvojenim zaključcima pružila punu podršku jačanju privredne saradnje i na taj način davala neophodne smernice i impuls vladama i drugim akterima ekonomskog života obe zemlje. Ovakav generalni stav političkih rukovodstava kao i praktični koraci koje su preduzimale vlade, ministarstva i drugi nadležni državni organi, veoma pozitivno su se odrazili na razvoj jugoslovensko-sovjetskih ekonomskih odnosa tokom 70-ih godina.

Tito i drugi članovi jugoslovenske delegacije su u razgovorima sa sovjetskim vođstvom tokom ovih poseta kao jedan od najvažnijih problema $\mathrm{u}$ jugoslovenskoj spoljnotrgovinskoj razmeni isticali visok spoljnotrgovinski deficit, posebno sa zapadnim zemljama, dok su razmenu sa istočnoevropskim socijalističkim zemljama karakterisali kao balansiranu, kakvu su očekivali i u daljem toku trgovinskog poslovanja sa Sovjetskim Savezom. ${ }^{6}$ Obe strane su bile saglasne u stavu o potrebi održavanja balansa u trgovinskoj razmeni tako da do kraja ovog perioda nije zabeležen značajniji trgovinski deficit ni na jugoslovenskoj niti na sovjetskoj strani, što je u svakom slučaju bilo od obostrane koristi s obzirom na okolnost da je u međusobnoj trgovini primenjivan klirinški način plaćanja.

${ }^{5}$ AJ-837-I- 3a-/101-145, Materijal o poseti Alekseja Kosigina Jugoslaviji 24-30. septembar 1973.

${ }^{6}$ AJ, 837-I-2/ 53, Stenografske beleške razgovora Brežnjev - Tito, Moskva. 
Sa strane sovjetskog političkog vrha iskazivana je, posle bitnog poboljšanja političkih odnosa 1972-1973, spremnost na manifestovanje solidarnosti, tj. za izlaženje u susret molbi jugoslovenske strane u pogledu snabdevanja energentima koje je bilo ugroženo izbijanjem naftne krize 1973. godine. Tako je na sastanku dveju delegacija prilikom Titove posete SSSR-u 12. novembra 1973, Brežnjev izjavio da je odmah po saznanju za tu molbu doneta odluka da se u Jugoslaviju uputi tanker sa 10.000 tona benzina, te da ako je potrebno može da se pošalje i 200.000 tona nafte na račun isporuka za 1974, zatim 80.000 tona lož ulja i 5.000 tona dopunske količine kerozina. $^{7}$

Povoljan politički ambijent i kontinuirana angažovanost relevantnih državnih organa i službi obe strane tokom 1972/73. stvorili su solidnu bazu za jačanje i širenje ekonomske kooperacije između Jugoslavije i SSSR-a. Rezultat takvih okolnosti bio je veliki uspon koji je počeo od sredine 1973. godine. Ni glavni akteri u kreiranju ekonomske saradnje nisu očekivali takav zamah i takve rezultate. To se jasno može videti iz srednjoročnih projekcija obima trgovinske razmene i drugih formi ekonomske saradnje i onoga što je bilo realizovano u praksi. Tako je prema sporazumu o robnoj razmeni za period 1971-1975. (potpisan februara 1971) bilo predviđeno da vrednost robne razmene $\mathrm{u}$ oba pravca bude 3,7 milijardi dolara, da bi ta brojka bila znatno premašena - dostigavši vrednost od 5,1 milijardu dolara. $\mathrm{Na}$ povećanje vrednosti $\mathrm{u}$ određenoj meri uticala je okolnost da je $u$ to vreme došlo do osetnog povećanja cena energenata i repromaterijala na svetskom tržištu (nafte i naftinih derivata, uglja, koksa, aluminijuma, pamuka, kože, vune i dr.), uglavnom robe koja je bila na listi sovjetskog izvoza u Jugoslaviju. To je primoravalo jugoslovensku stranu da poveća obim proizvoda koje je izvozila u SSSR kako bi se održao balans u ukupnoj robnoj razmeni. Tokom 1974. i 1975. došlo je do znatnog proširenja asortimana i količine jugoslovenske robe, naročito u oblasti mašinogradnje i hemijske industrije, što je uticalo na vidan porast vrednosti ukupne robne razmene koja je u 1974. dostigla iznos od 1,6, a 1975, oko 2 miliona dolara, čime je Sovjetski Savez izbio na prvo mesto kao spoljnotrgovinski partner Jugoslavije. $^{8}$

Ohrabreni ovakvim rezultatom, jugoslovenski i sovjetski pregovarači su sklopili novi sporazum o robnoj razmeni za period 1976-1980. (potpisan novembra 1975) koji je predviđao vrednost razmene od 14,2 milijarde dolara, što je bilo povećanje za oko 2,4 puta u odnosu na ostvareno u prethodnom petogodišnjem periodu. Ovaj generalni sporazum pratilo je nekoliko posebnih sporazuma od kojih su najvažniji bili: sporazum o međusobnoj

\footnotetext{
${ }^{7}$ AJ, 837-I-2/55, Stenografske beleške razgovora Brežnjev - Tito, 12. novembar 1973.

${ }^{8}$ Jugoslovenski pregled, 1981, br. 7-8, 329.
} 
isporuci brodova i brodske opreme, sporazum o automobilskoj industriji i sporazum o kooperaciji u proizvodnji opreme za nuklearne elektrane. Sporazumom iz oblasti brodarstva bio je predviđen izvoz jugoslovenskih morskih i rečnih plovila $u$ vrednosti od 570 miliona dolara i uvoz iz SSSR-a manjih brodova za prevoz suvog tereta i putnika u vrednosti od oko 100 miliona dolara (jugoslovenski izvoz bio je najvećim delom ostvaren, dok su sovjetske isporuke plovila samo delimično realizovane). Sporazumom o automobilskoj industriji bila je predviđena saradnja i međusobne isporuke između fabrike automobila „Crvena zastava“ iz Kragujevca i Volškog automobilskog zavoda (VAZ) u vrednosti 50-70 miliona dolara godišnje i sprovođenje ovog sporazuma se dosta uspešno odvijalo. Prema sporazumu o saradnji u proizvodnji za nuklearne elektrane bile su predviđene značajne isporuke jugoslovenske opreme iz te oblasti čija je vrednost za ovaj petogodišnji period dostizala 320 miliona dolara. Realizacija ovog zahtevnog programa sprovođena je preko jugoslovenske poslovne zajednice mašinogradnje i elektromašinogradnje (YUMEL), a u tome su učestvovale najznačajnije firme iz te branše: „Energoinvest" iz Sarajeva, „Jugoturbina“ iz Karlovca, „Litostroj" iz Ljubljane, „Đuro Đaković" iz Slavonskog Broda i „Prva iskra" iz Bariča kod Beograda. ${ }^{9}$

Ukupna vrednost jugoslovensko-sovjetske robne razmene $\mathrm{u}$ ovom petogodišnjem periodu dostigla je 17 milijardi dolara, dakle oko 3 milijarde dolara više nego što je bilo predviđeno. No, ovaj rezultat nije bio samo plod povećanja i proširenja isporuka, već je jednim delom bio i posledica porasta cena proizvoda uključenih u ovu razmenu. Odigrala se i značajna izmena $u$ strukturi jugoslovenskog izvoza u SSSR ovih godina budući da su sve veći udeo zauzimali mašinogradnja i metalurška oprema. Izvoženi su: mašine alatljike, transformatori i transformatorske podstanice, oprema za prehrambenu i pekarsku industriju, oprema za ugostiteljstvo i trgovinu, telefonske centrale, proizvodi elektronske i radio industrije i drugo. Vrednost ovog izvoza u periodu 1976-1978. iznosila je oko 3 milijarde dolara, što je činilo skoro polovinu jugoslovenskog izvoza u SSSR.

Repromaterijal i sirovine predstavljali su značajnu stavku u jugoslovenskom izvozu. Izvoženi su: boksit, glinica, silicijum, olovo, cink, antimon, valjani materijali crne i obojene metalurgije, boje, lakovi, drvna građa, sredstva za zaštitu bilja, razni hemijski proizvodi. Ukupna vrednost izvezenih proizvoda u ovom petogodišnjem razdoblju iznosila je 2,4 milijarde dolara. Važno mesto u jugoslovenskom izvozu zauzimala je roba široke potrošnje čija je vrednost dostigla 2,6 milijarde dolara što je bilo oko 800 miliona dolara više nego što je bilo predviđeno sporazumom o robnoj razmeni za

\footnotetext{
${ }^{9}$ Isto, 330.
} 
period 1976-1980. godina. Izvoženi su obuća (10-12 miliona pari godišnje), konfekcija, trikotaža, razne vrste tkanina, tepisi, nameštaj, električni i plinski štednjaci, kristalno posuđe, lekovi i drugo. ${ }^{10}$

Primetna je bila slaba zastupljenost poljoprivrednih i prehrambenih proizvoda u jugoslovenskom izvozu. U posmatranom periodu udeo ovih proizvoda u ukupnom izvozu činio je samo 1\%. Sporazumom je bio predviđen izvoz mesnih konzervi, semena i sadnica, suvih šljiva, duvana i manje količine alkoholnih pića. Krajem ovog perioda (1979-1980) sovjetska strana je pokazala interes za uvoz većih količina ovih proizvoda i proširenje asortimana, tako da su u liste izvoza uvršteni konzervirano voće i povrće, voćni sokovi, testenine, dečija hrana, supe i dodaci jelima i drugo. Usled ovakvog trenda osetno se povećavao udeo poljoprivrednih i prehrambenih artikala, dostigavši u 1980. godini 10\% vrednosti ukupnog jugoslovenskog izvoza u SSSR.

Tako mali udeo ovih proizvoda u jugoslovenskom izvozu bio je odraz tadašnje sovjetske političke i socijalne stvarnosti. Sovjetska strana nije bila spremna da konstantnu nestašicu proizvoda ove vrste sanira uvozom koji bi zadovoljio potrebe građana jer je to zahtevalo izdvajanje ogromnih finansijskih sredstava, uglavnom deviznih, koja su nedostajala, tako da su se ograničavali na nabavke neophodnih poljoprivrednih artikala, na prvom mestu pšenice, naročito u godinama kada su bile oskudne žetve. Jednom rečju uvozom se nije mogao rešiti problem hroničnih nestašica poljoprivrednih proizvoda kao ni robe široke potrošnje. Taj problem je iz godine u godinu postajao sve izraženiji, zadržavajući se na društvenoj sceni sve do kolapsa komunističkog sistema i raspada SSSR-a, a nezadovoljstvo građana koje je zbog toga raslo bilo je jedan od simbola neuspešnosti socijalističkog sistema sovjetskog tipa i jedan od glavnih faktora njegove propasti. Ovome treba dodati da Jugoslavija ni izdaleka nije imala kapaciteta da svojim izvozom u značajnijoj meri zadovolji realne potrebe SSSR-a i u slučaju da je sa sovjetske strane bilo potraživanja za isporuku veće količine i šireg asortimana poljoprivrednih i prehrambenih proizvoda.

Struktura jugoslovenskog uvoza iz SSSR-a tokom oba posmatrana petogodišnja perioda nije se bitnije menjala. Najveći udeo u uvozu zauzimale su sirovine i repromaterijal, na prvom mestu nafta i naftini derivati (ukupno za period 1976-1980. godina 20 miliona tona), zatim ugalj za koksovanje, antracit, prirodni gas, rude gvožđa, mangana i hroma, azbest, sirovo gvožđe, materijali crne metalurgije, aluminijum, kalijumove soli, sintetički kaučuk, celuloza, pamuk, sirova koža i drugo. ${ }^{11}$ Važnu komponentu

${ }^{10}$ Isto.

${ }^{11}$ Osim nafte i naftnih derivata, u čemu je SSSR raspolagao sa ogromnim potencijalom i snažnim proizvodnim kapacitetima, ovih godina je na scenu stupao i gas kao energent sa velikom 
činile su mašine i oprema: alatne mašine, rudarska i energetska oprema, proizvodi elektromašinogradnje, putnička i teretna vozila, traktori, građevinske mašine, proizvodi radio i elektronske industrije, avioni, helikopteri i drugo. Vrednost ove vrste proizvoda u periodu 1976-1980. iznosila je oko 900 miliona dolara. Vrednost ovog uvoza u periodu 1976-1980. bila je 6,2 milijarde dolara. Roba široke potrošnje predstavljala je neznatnu stavku u jugoslovenskom uvozu iz SSSR-a (oko 1\%); lista ove vrste robe svodila se uglavnom na satove, foto-aparate i kamere, sportsko i lovačko oružje, ukupne vrednosti oko 75 miliona dolara za period 1976-1980. godina. ${ }^{12}$

Pored robne razmene koja je činila okosnicu ekonomske saradnje između dve zemlje, $u$ posmatranom periodu su postignuti i prvi krupniji rezultati na planu industrijske kooperacije. Uz automobilsku industriju i proizvodnju opreme za nuklearne elektrane, ostvarena je kooperacija i u proizvodnji privrednih vozila između „Progresa“ iz Beograda i „Avto-exporta“ iz Moskve u proizvodnji teških kamiona „Kamaz“. Sa jugoslovenske strane u ovom poslu su učestvovala mnoga preduzeća mašinske i elektronske industrije, „Prva petoletka“ iz Trstenika, „Rude Čajavec“ iz Banja Luke, "Saturnus“ iz Ljubljane, „Utva“ iz Pančeva, „Goša“ iz Smederevske Palanke. Ostvarena je saradnja i u proizvodnji sovjetskih bagera u kojoj su sa jugoslovenske strane učestvovali „14. oktobar" iz Kruševca, „Radoje Dakić“ iz Titograda i MIN iz Niša. Bilo je još nekoliko manjih aranžmana o kooperaciji između jugoslovenskih i sovjetskih preduzeća, uglavnom na polju metalne industrije i mašinogradnje.

U ovom periodu sklopljen je i sporazum o međudržavnom kreditu (novembra 1972) kojim je SSSR odobrio 540 miliona dolara za izgradnju i rekonstrukciju energetskih i industrijskih objekata u Jugoslaviji. Kredit je 1977. uvećan za daljih 210 miliona dolara kako bi se mogao realizovati ceo predviđeni program koji je obuhvatao 42 objekta. Do kraja 1980. od ovog kredita izgrađeni su objekti u vrednosti od 662 miliona dolara.

Značajna saradnja je ostvarena u oblasti građevinarstva. Uspon na ovom polju otpočeo je posle dogovora koji je postignut na zasedanju Mešo-

perspektivom u budućnosti. O planovima, nadama i velikim mogućnostima u proizvodnji i izvozu ovog proizvoda govorio je Leonid Brežnjev na sastanku sovjetske i jugoslovenske delegacije prilikom Titove posete SSSR-u novembra 1973. godine. Govoreći o „bilijardama, trilijardama“" kubnih metara gasa, Brežnjev je rekao da sovjetski stručnjaci ulažu ogromne napore i velika sredstva za sprovođenje tehničko-tehnološkog procesa za eksploataciju ove sirovine. Istakavši da je to nacionalno bogatstvo, da rezervi ima za narednih dvadeset godina i da se raduje kad gleda u budućnost, on je kazao da to znači mnogo ne samo za SSSR već i za druge istočnoevropske socijalističke zemlje i Jugoslaviju, te da nafta i gas predstavljaju sirovine koje omogućuju saradnju i sa kapitalističkim zemljama i to ne samo kratkoročno već i dugoročno, na 20-30 godina. - AJ, 837-I-2/55, Stenografske beleške razgovora Brežnjev - Tito, 12. novembar 1973.

${ }^{12}$ Jugoslovenski pregled, 1981, br. 7-8, 330 . 
vitog jugoslovensko-sovjetskog komiteta za privrednu saradnju 1972. godine. Sovjetska strana je predložila da jugoslovenska građevinska preduzeća izgrade turističko-ugostiteljski centar na Jalti, kao i još nekoliko hotela i drugih objekata u Moskvi i južnim oblastima SSSR-a. Radi realizacije saradnje u ovoj oblasti, mešoviti komitet je obrazovao posebnu radnu grupu. Tim povodom jugoslovenske građevinske firme zainteresovane za gradnju u SSSR-u potpisale su sporazum o koordiniranom nastupu na sovjetskom tržištu, a poslovne zajednice „Union-inžinjering“ iz Beograda i "Ingra“ iz Zagreba su u tom pogledu dobile izvršna ovlašćenja. Pošto se iz godine u godinu građevinska delatnost jugoslovenskih firmi u SSSR-u veoma uspešno razvijala, bilo je i preduzeća, na primer „Kongrap“ iz Beograda, koja su sklapala direktne aranžmane sa sovjetskim investitorima i ulazila u kooperaciju sa partnerima iz trećih zemalja. Ovaj angažman jugoslovenske građevinske industrije u SSSR-u pokazao se vrlo uspešnim i isplativim. Osim zapošljavanja hiljada radnika na ovim poslovima, jugoslovenske firme su angažovale i svoju opremu, a i deo građevinskog materijala je isporučivan iz Jugoslavije. Ukupna vrednost građevinskih radova jugoslovenskih preduzeća izvedenih u SSSR-u do kraja 1980. iznosila je oko 370 miliona dolara. ${ }^{13}$

I pored optimističkih projekcija i inicijativa, nije ostvarena značajnija saradnja na planu zajedničkog nastupa na trećim tržištima. Ona je ostala u skromnim okvirima do kraja ovde posmatranog perioda. Uz nekoliko manjih kooperacija ostvarenih u izgradnji i opremanju privrednih objekata u Turskoj, Iranu i Pakistanu, najveći zajednički poduhvat bila je izgradnja termoelektrane u Iraku (Basra) kapaciteta od $100 \mathrm{MW}$, pri čemu su jugoslovenska preduzeća („Rad“ i „Minel“) izvršila građevinske radove i ugradila opremu koju je isporučila sovjetska strana.

Unapređena je saradnja i u oblasti saobraćaja, što je bilo neophodno s obzirom na povećanje količine robe koja se razmenjivala u oba pravca. Naročite teškoće, povremeno i zagušenja, nastajale su u železničkom saobraćaju, posebno zbog porasta jugoslovenskih isporuka u SSSR. U težnji da se ove teškoće umanje vagoni iz Jugoslavije su, osim preko Mađarske, usmeravani i na granične prelaze preko Rumunije. Procena obe strane je bila da se ovi problemi mogu prevazići većim uključenjem drumskog saobraćaja tako da je od 1979. ovaj vid saobraćaja značajno povećan. Došlo je i do intenziviranja turističke saradnje, u vezi s čim je 1972. potpisan međudržavni sporazum. U turističkoj razmeni gotovo isključivo su praktikovane grupne posete. Najviši nivo je dostignut 1979. kada je u oba pravca zabeleženo 231.000 turista, od čega 197.000 sovjetskih i oko 34.000 jugoslovenskih. ${ }^{14}$

${ }^{13}$ Isto. - Plaćanje građevinskih radova takođe je vršeno u kliringu, a balansiranje se obavljalo preko robnih lista.

${ }^{14}$ Isto, 331. 
$\mathrm{Na}$ uspon ekonomske saradnje između Jugoslavije i SSSR-a u posmatranom periodu, koji se prvenstveno ogledao kroz proširenje i rast robne razmene, osim povoljnog političkog ambijenta, snažno su uticali i sama ekonomska logika i interesi. Naime, i za jednu i za drugu privredu koje su bile u prilično lošem stanju - opterećene neefikasnim poslovanjem kao posledicom primene koncepta državnog vlasništva i državne regulative $\mathrm{u}$ privredi i sve izraženijeg tehnološkog zaostajanja za zapadnim zemljama (s tim što su u Jugoslaviji bili znatno više bili uključeni elementi tržišne ekonomije) - pitanje ekonomskih odnosa sa inostranstvom se postavljalo kao jedno od najbitnijih za dalji privredni razvoj. Glavni problem predstavljao je nedostatak deviznih sredstava, što je limitiralo mogućnosti trgovine i drugih oblika poslovanja na konvertibilnom području. Pored toga SSSR se suočavao i sa ograničenjima koje su zapadne zemlje uspostavile na planu trgovine, kao i sa praktičnim onemogućavanjem transfera tehnoloških inovacija sovjetskoj strani. Jugoslavija je u tom smislu bila u daleko povoljnijem položaju. Iz ovih razloga su politička rukovodstva i vlade dve zemlje imale evidentan interes da maksimalno razvijaju trgovinsku i druge oblike ekonomske saradnje na bazi klirinškog, a ne deviznog plaćanja. Posebno se to odnosilo na Jugoslaviju, na prvom mestu zbog povoljnih efekata koje je imala kroz uvoz nafte i drugih energenata iz SSSR-a čime je dobrim delom uspevala da supstituiše uvoz tih proizvoda na bazi plaćanja u konvertibilnoj valuti.

Povoljnu okolnost za razvoj ekonomske saradnje predstavljala je činjenica da su privrede dveju zemalja bile komplementarne. Bilo je, dakle, dosta proizvoda koje su jednoj strani nedostajali a koje je druga strana bila u stanju da isporučuje. Za jugoslovensku stranu to su na prvom mestu bili energenti, sirovine i oprema za industrijska postrojenja, pogotovu za ona iz oblasti tzv. teške industrije i elektroprivrede. Sovjetska strana je najviše bila zainteresovana za uvoz brodova, mašina, elektronske opreme i aparata, robe široke potrošnje. Efekti dinamičnog uspona ekonomske saradnje u ovom periodu bili su povoljni za obe strane. Oni su se, s obzirom na razliku u veličini ovih zemalja i ekonomija, više odražavali na Jugoslaviju, o čemu svedoči i podatak da je od 1975. SSSR izbio na prvo mesto u njenoj trgovinskoj razmeni sa inostranstvom (oko 22\% ukupne spoljnotrgovinske razmene). Međutim, i Jugoslavija je usled visoke stope rasta robne razmene tih godina postala respektabilan partner SSSR-u - svrstavši se u 10 najvećih spoljnotrgovinskih partnera (deveto mesto).

O obimu, značaju i koristi ekonomske saradnje između Jugoslavije i SSSR-a za obe zemlje tokom 70 -ih godina 20 . veka ubedljivo govori podatak da je ukupna robna razmena 1980. imala vrednost od oko 5,2 milijardi dolara. 
Djoko Tripković

THE GROWTH OF THE ECONIMICAL COOPERATION

BETWEEN THE YUGOSLAVIA AND THE SOVIET UNION 1971-1980

\section{Summary}

The economical relations between the Yugoslavia and Soviet Union during the 1970-ties, are the subject of this article. This decade was the period of the dynamical development of the economical cooperation between the two states. The economical relations rised after the exchange of the visits of the two presidents: Brezhnyev's to Yugoslavia in 1971 and Tito's to USSR in 1972 and 1973. Stability of the political relations was the pretext for such excellent and widespread economical cooperation, but both sides have the developed interest in strengthening the economical ties and relations. The mutual goods exchange reached high peak, while the important results came out from the industrial cooperation and building. Soviet Union became highest positioned economical partner for Yugoslavia in 1975. Comparing the 1971 and 1980 it was evident that the mutual good exchange, have over ten times growth. 